\title{
Bioaccumulation of Heavy Metals in Lycopersicon Esculentum Grown with Tannery Sludge across Some Selected Farmlands in Dawakin Kudu LGA of Kano State, Nigeria
}

\author{
Abigail Clement Young ${ }^{* 1}$, Muhammad Ibrahim ${ }^{2,3}$

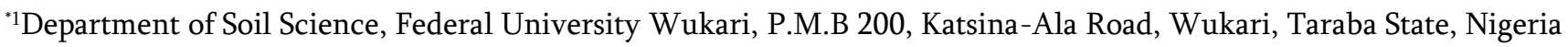 \\ ${ }^{2}$ Department of Environmental Management and Toxicology, Federal University Dutse, 720101, Jigawa State, Nigeria \\ ${ }^{3}$ College of Environment, Hohai University, Nanjing, 210098, P. R. China
}

\section{Article Info}

Volume 8, Issue 2

Page Number : 251-257

\section{Publication Issue}

March-April-2021

\section{Article History}

Accepted : 25 March 2021

Published : 28 March 2021

\section{ABSTRACT}

Human health has been adversely exposed to many inauspicious threats due to human activities. Evidently, ecotoxicological studies documented that industrial and agricultural wastes tremendously contribute to the contemporary environmental pollution and subsequent associated health issues. Meanwhile, the application of tannery sludge as fertilizer has been recently reported in Dawakin Kudu LGA of Kano State, Nigeria and this sludge was suspected to have contained a large quantity of toxic metals. This study was aimed to investigate the presence of toxic metals including $\mathrm{Cd}, \mathrm{Cr}$ and $\mathrm{Pb}$ in the fruits of Tomato (Lycopersicon esculentum) grown with tannery sludge in the selected farms in the study area in order to ascertain their suitability for human consumption. The toxic metals $(\mathrm{Cr}, \mathrm{Cd}$ and $\mathrm{Pb})$ were found to be incorporated into the tissue of tomato's fruits and were all above the permissible limits of WHO/FAO except for the $\mathrm{Cr}$ in sampling location 1 and 2 , and $\mathrm{Pb}$ in location

2. The study also demonstrated that $\mathrm{pH}$ of the soil influence the rate of uptake of heavy metals into tomato cells. Analysis of variance (ANOVA) at $p<0.05$ revealed that there is no significant difference in the concentration of heavy metals between and within groups while pollution index for metals like $\mathrm{Cd}$ has indicated a potential pollution. It was recommended that leather industries should dispose wastes far from residential areas and out of reach of farmers while coming up with tertiary methods of sludge treatment before disposal.

Keywords: Lycopersicon Esculentum, tannery sludge, Dawakin Kudu, Bioaccumulation, toxic metals

\section{INTRODUCTION}

During the last two decades, the increasing demand of food safety has stimulated research regarding the risk associated with the consumption of heavy metal contaminated foods. Heavy metals can enter the human body through consumption of food crops grown in metal contaminated soil. However, the prediction of exposure to potentially toxic metals from the ingestion of these crops is more complicating 
because uptake of metal by plants depends on soil properties and plant physiologic factors (Oyeleke et al., 2015; Abdallah et al., 2017; Khadija \& Ibrahim, 2019).

Heavy metals are non-biodegradable, toxic and persistent environmental contaminants that have devastating effects in living systems(Ibrahim et al., 2017). The tendencies of these heavy metals to bioaccumulate in biological systems makes them a potential health hazard due to their toxicity by which they break down the immune system and serve as pathways for the occurrence of different diseases.

Nanven and associates (2015) carried out an assessment of heavy metals in some vegetables grown in a farm treated with urban solid waste in Kuru Jantar, Plateau State, Nigeria. Following their research, the use of dumpsite soils as organic manure is widespread in Plateau and the practice is upheld because it improves soil characteristics such as organic matter, nutrients, porosity, water retention, aggregate stability, and bulk density and as a result increases plant productivity. (Ogunyemi et al., 2003; Oluyemi et al., 2008).

Most of the leather industries process raw hides and skins to a leather products. A lot of wastes, both liquid and solid, is generated and indiscriminately discharged into the nearby waterways and dumpsites (Angela et al., 2019; Ibrahim, 2019). Although the effluents are treated in treatment plants, the resultant dry cake known as sludge, possesses some toxic slurry of chemical constituents of which heavy metal is a key. According to Gupta and Sinha (2007), high content of inorganic elements such as Chromium (Cr), Cadmium (Cd), Nickel $(\mathrm{Ni})$, and Lead $(\mathrm{Pb})$ exist in tannery sludge and these could lead to environmental pollution and damage to human health.

The farmers grow vegetables and cereals for household consumption and sell the surplus to other villagers at the local market. Basically, environmental health concerns arise when this sludge is used by farmers to grow vegetables like tomato, pepper, onions, lettuce to mention but a few, and cereals like maize and millet (Brempong et al., 2019). The potential bioaccumulation of these heavy metals from the tannery - sludge amended soil could constitute high risks and the danger of spread of epidemic diseases lying in the ultimate consumption of plants such as tomatoes grown with the tannery sludge necessitates the analysis of its fruits. Therefore this study was aimed to assess the level of heavy metals accumulated in the fruits of the tomatoes grown with tannery sludge.

\section{METHODS AND MATERIAL}

\subsection{Materials}

\subsubsection{Plant Material}

This study utilized the fruits of Tomato (Lycopersicon esculentum) as the plant material for the study.

\subsubsection{Reagents}

Nitric acid $\left(\mathrm{HNO}_{3}\right)$ with analytical grade of $69-72 \%$, $30 \%$ Hydrogen Peroxide $\left(\mathrm{H}_{2} \mathrm{O}_{2}\right)$, nitrates of $\mathrm{Cr}, \mathrm{Pb}$ and $\mathrm{Cd}$ (to be used in preparing stock solutions (1000 $\mathrm{mg} / \mathrm{L}$, in $2 \% \mathrm{HNO}_{3}$ ) of the metal ions and Deionized water (used as diluent for preparing desired working standards of the metal ion solutions).

\subsubsection{Research Tools}

The materials used in this research include, sample containers mortar and Pestle, $2 \mathrm{~mm}$ sieve, drying oven, weighing balance, crucibles, pair of tongs, beakers, standard volumetric flasks, whatman filter paper No 42, watch glass, hot plate, refrigerator, and Atomic Absorption Spectrophotometer (Buck Scientific 200A Model).

\subsection{Methods}

\subsubsection{Samples and Sampling Technique}

\subsubsection{Plant samples}


Plant samples from three different mega farms in Dawakin Kudu LGA of Kano State were collected purposefully. One farm where tannery sludge was not used served as control to be used in comparing the concentration of heavy metals in the other two farms where tannery sludge was applied. All sampled plants were oven dried to constant weight using standard laboratory drying oven and analytical precision weighing machine ( 0.001 precision) at $70^{\circ} \mathrm{C}$ overnight and weighed to estimate the plant biomass concentration in $\mathrm{mg} / \mathrm{kg}$.

\subsubsection{Sample Preparation}

The plant samples were taken to the Chemistry laboratory, Federal University Dutse, Nigeria where they were properly washed with $20 \%$ Nitric acid, rinsed with deionized water and oven dried at $70{ }^{\circ} \mathrm{C}$ for 24 hours until a steady weight was attained. The oven dried plant tissues were then pounded with crucible to fine powder and sieved through a $2 \mathrm{~mm}$ sieve, and transferred into a well labeled container for easy identification and laboratory analysis (figure 1a).

\subsubsection{Laboratory Analysis of Plant Samples}

Two gram of each plant sample was weighed into Erlenmeyer flask using the US EPA 3050 method. As depicted in figure $1(\mathrm{~b}), 20 \mathrm{~mL}$ of $\mathrm{HNO}_{3}$ was added and the mixture was allowed to boil for 20 minutes on a hot plate at $100{ }^{\circ} \mathrm{C}$. The digest was then allowed to cool and another $10 \mathrm{~mL}$ of $\mathrm{HNO}_{3}$ was added and heating continued for 30 minutes at $100{ }^{\circ} \mathrm{C}$. The digest was further allowed to cool. $10 \mathrm{~mL}$ of deionized water (DIW) was added when effervescence subsided and $20 \mathrm{~mL}$ of $60 \% \mathrm{H}_{2} \mathrm{O}_{2}$ was added and heating continued for another 15 minutes. The final digest was allowed to cool and then filtered. The final volume of digest was made up to $50 \mathrm{~mL}$ with DIW after which it was labeled and stored in a refrigerator for AAS analysis. The metal analysis was conducted in the Soil and Water Lab, Department of Geography, Bayero University Kano, Nigeria. Prior to analysis, the wave length, lamp current, burner alignment and slit width was optimized for each element. PuroGraphic $^{\mathrm{TM}}$ standards of Buck Scientific Model for AAS standards in $2 \%$ nitric acid for each metal was used.

\subsubsection{Statistical Analysis}

Data collected was analyzed using Descriptive Statistics and Analysis of Variance (ANOVA) in SPSS and Excel ToolPak. The probability level of certainty in the research was at $95 \%$ confidence limit or $\alpha=$ 0.05 .
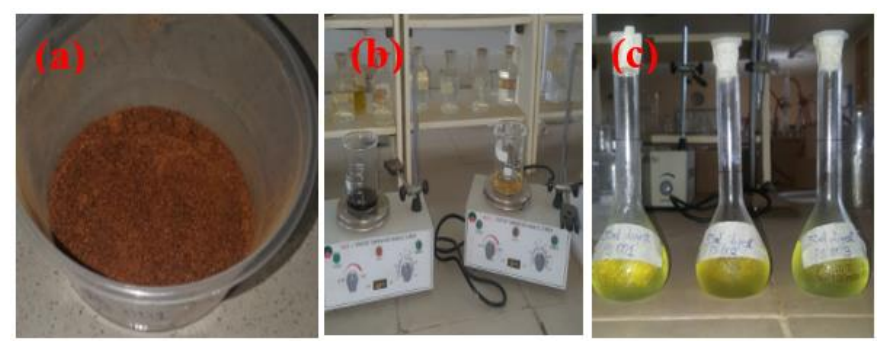

Figure 1: (a) tomato plant samples after grinding (b) hot plates used for digestion (c) Plant digest for AAS analysis

\section{RESULTS AND DISCUSSION}

\subsection{Results}

Table 1: Concentration of heavy metals in tomato plant samples

\begin{tabular}{|c|c|c|c|}
\hline $\begin{array}{l}\text { Sample } \\
\text { ID }\end{array}$ & $\begin{array}{l}\mathrm{Cr} \\
(\mathrm{mg} / \mathrm{kg})\end{array}$ & $\begin{array}{l}\mathrm{Cd} \\
(\mathrm{mg} / \mathrm{kg})\end{array}$ & $\begin{array}{l}\mathrm{Pb} \\
(\mathrm{mg} / \mathrm{kg})\end{array}$ \\
\hline PSL 001 & 1.85 & 5.0 & 4.35 \\
\hline PSL 002 & 3.7 & 7.5 & 1.1 \\
\hline PSL 003 & 1.85 & 10.0 & 3.26 \\
\hline
\end{tabular}

Where PSL = Plant Sampling Location

Table 2: Instrumental operating conditions

\begin{tabular}{|l|l|l|l|l|}
\hline $\begin{array}{l}\text { Eleme } \\
\mathrm{nt}\end{array}$ & $\begin{array}{l}\text { Wave } \\
\text { length(n } \\
\mathrm{m})\end{array}$ & $\begin{array}{l}\text { Detection } \\
\text { limit(mg/ } \\
\mathrm{L})\end{array}$ & $\begin{array}{l}\text { Slit } \\
\text { width(n } \\
\mathrm{m})\end{array}$ & $\begin{array}{l}\text { Lamp } \\
\text { Current(m } \\
\text { A) }\end{array}$ \\
\hline $\mathrm{Cr}$ & 357.9 & 0.03 & 0.7 & 2 \\
\hline $\mathrm{Cd}$ & 228.8 & 0.005 & 0.7 & 2 \\
\hline $\mathrm{Pb}$ & 283.3 & 0.1 & 0.7 & 2 \\
\hline
\end{tabular}


Table 3 : Absorbance values as displayed by AAS Buck Scientific VGP 210

\begin{tabular}{llll}
\hline Sample ID & $\mathrm{Cr}$ & $\mathrm{Cd}$ & $\mathrm{Pb}$ \\
\hline PSL 001 & 0.002 & 0.002 & 0.004 \\
PSL 002 & 0.004 & 0.003 & 0.001 \\
PSL 003 & 0.002 & 0.004 & 0.003 \\
\hline
\end{tabular}

Calibration curves for each heavy metal was generated. Using the relationship below, heavy metal concentration in $\mathrm{mg} / \mathrm{kg}$ was determined.

$$
\mathrm{x}=\frac{\mathrm{y}}{\text { slope }} \mathrm{x} \frac{\text { volume of digest }}{\text { weight of sample }} \ldots \ldots \ldots . . . . \text { eq. } 1
$$

Where;

$\mathrm{x}=$ Concentration in $\mathrm{mg} / \mathrm{kg}$

$\mathrm{y}=$ absorbance values

Slope values for $\mathrm{Cr}, \mathrm{Cd}$ and $\mathrm{Pb}=0.027,0.010$ and 0.023 respectively.

Volume of digest $=50 \mathrm{~mL}$

Weight of plant sample $=2 \mathrm{~g}$

Table 4: Pollution indices for heavy metals in tomato plant

\begin{tabular}{cccc}
\hline Samples & Cr & Cd & Pb \\
\hline PSL 001 & 0.80 & 5.00 & 2.18 \\
PSL 001 & 1.60 & 7.50 & 0.55 \\
PSL 003 & 0.80 & 10.0 & 1.60 \\
\hline
\end{tabular}

Table 5: ANOVA of plant samples (a) Mean and variance in plant samples

\begin{tabular}{lllll}
\hline Groups & Count & Sum & Average & Variance \\
\hline PS 001 & 3 & 11.2 & 3.733333 & 2.765833 \\
PS 002 & 3 & 12.3 & 4.1 & 10.36 \\
PS 003 & 3 & 15.11 & 5.036667 & 18.97303 \\
\hline
\end{tabular}

\begin{tabular}{lrrcccc} 
(b)ANOVA & & & & & & \\
\hline $\begin{array}{l}\text { Source of } \\
\text { Variation }\end{array}$ & SS & df & MS & F & P-value & F crit \\
\hline Between & & & & & & \\
Groups & 0.646822 & 2 & 0.323411 & 0.376702 & 0.701271 & 5.143253 \\
Within & & & & & & \\
Groups & 5.1512 & 6 & 0.858533 & & & \\
Total & 5.798022 & 8 & & & & \\
\hline
\end{tabular}

\subsection{Discussion}

\subsubsection{Heavy Metals in Tomato}

3.2.1.1 The Chromium (Cr) content in the tomato's fruits

From Table 1, the concentration of Cr in PSL 001 and PSL $\overline{0} 03$ (control) was below threshold of $2.3 \mathrm{mg} / \mathrm{kg}$ (Weigert,1991) and they showed pollution indices (PI) less than 1 (PI $<1$ ) thus indicating an absence of pollution (Table 4). PSL 002 had high $\mathrm{Cr}$ content $(3.7 \mathrm{mg} / \mathrm{kg}$ ) and PI greater than 1 indicating severe pollution. The above threshold values obtained for the tomato plant sample indicated the evidence of $\mathrm{Cr}$ bioaccumulation.

\subsubsection{The Cadmium (Cd) content in the tomato's fruits}

$\mathrm{Cd}$ was found to exceed $1.0 \mathrm{mg} / \mathrm{kg}$, the stipulated $\mathrm{WHO} / \mathrm{FAO}$ guideline for metals in vegetables, in all 
the samples with concentrations ranging from $5.0 \mathrm{mg} / \mathrm{kg}-10.0 \mathrm{mg} / \mathrm{kg}$. It is paramount noting that the severity of Cd pollution was high (PI > 1) and Cd was significantly concentrated in the tomato's fruit as shown in Figure 2.

\subsubsection{The Lead $(\mathrm{Pb})$ content in the tomato's fruits}

For $\mathrm{Pb}$, in PSL 001 and PSL 003 (control) metal concentrations were $4.35 \mathrm{mg} / \mathrm{kg}$ and $3.26 \mathrm{mg} / \mathrm{kg}$, respectively. These values were above threshold of $2.0 \mathrm{mg} / \mathrm{kg}$ (WHO/FAO, 1989) with pollution indices standing at 2.18 and 1.6 , respectively which invariably reflected a severe pollution Table 4 . PSL 002 however showed $\mathrm{Pb}$ concentration within safe limits $(1.1 \mathrm{mg} / \mathrm{kg})$, it was deduced that there was no bioaccumulation of the metal in the plant and pollution index of $\mathrm{PI}<1(0.55)$ showed that there was no pollution (Table 4).This could be as a result of different factors such as rate of volatilization, translocation effects and rhizosphere condition. More often plants accumulate heavy metal at extremely high concentrations without manifesting damages due to transforming effect caused by interdependent action of metal and chelator molecules (Gupta and Sandalion, 2012).

In recent times, researchers have reported that so many types of vegetables such as spinach, carrot, lettuce, radish, tomato, and chickpea were contaminated by heavy metals of $\mathrm{Pb}, \mathrm{Cd}, \mathrm{As}, \mathrm{Zn}$ and $\mathrm{Cu}$ (Cobb 2000; Arora et al. 2008; Astawan 2008). The high levels of heavy metals was found to be contained in vegetables grown in polluted area or agricultural soils, such as soils located close to roadway, nearby smelter, and soils irrigated with wastewater (Cui et al. 2004; Kachenko and Singh 2004; Okoronkwo et al. 2005; Behbahaninia and Mirbagheri 2008). Hence, it was concluded that vegetables, particularly leafy crops, grown in polluted soils would typically contain higher concentration of heavy metals than those grown in unpolluted soils (Voutsa et al. 1996; Ibrahim et al., 2017). The high heavy metal content found in the control might be traced to the waterways, or a polluted industrial wastewater used to irrigate the plants.

\subsubsection{Analysis of Variance (ANOVA)}

The non-parametric Analysis of Variance at $\mathrm{p}<0.05$ revealed that there is no significant difference or variability in the concentration of heavy metals within and between groups. It can be observed that the F calculated is less than the F critical ( $p>0.05$ ), this gives sufficient evidence that there is no significant difference in the concentration of heavy metals within and between groups (Table 5a and b).

\subsubsection{The relationship between the soil $\mathrm{pH}$ and metal uptake by tomato}

Figure 3 showed different concentrations of $\mathrm{Cr}, \mathrm{Cd}$ and $\mathrm{Pb}$ with respect to $\mathrm{pH}$ values of the soil on which the tomato plants grew. The highest concentration of Cd $(10.0 \mathrm{mg} / \mathrm{kg})$ was detected in those tomatoes grown at slightly acidic soil ( $\mathrm{pH}$ 6.80). In contrast, the concentration of $\mathrm{Cr}$ (3.70) was found in the tomatoes that were cultivated on the neutral soil ( $\mathrm{pH}$ 7.2). Conversely, the highest concentration of $\mathrm{Pb}$ was examined to be $4.35 \mathrm{mg} / \mathrm{kg}$ and $3.26 \mathrm{mg} / \mathrm{kg}$ in tomatoes raised on soil with $\mathrm{pH} 7.0$ and 6.8, respectively. This outcome therefore, presented the evidence that tomatoes cultivated in slightly acidic environment might have greater risk of being polluted by $\mathrm{Cd}$. Whereas, $\mathrm{Cr}$ can be easily bioaccumulated into tissue of tomato plants at neutral $\mathrm{pH}$ environment. However, the $\mathrm{Pb}$ representation showed the dynamicity of taking up highly at $\mathrm{pH} 7.0$ and likewise in slightly acidic environment.

\section{CONCLUSION}

The concentration of $\mathrm{Cr}, \mathrm{Cd}$ and $\mathrm{Pb}$ incorporated into the tissue of tomato's fruits were all above the permissible limits of WHO/FAO except for the $\mathrm{Cr}$ in sampling location 1 and 2 , and $\mathrm{Pb}$ in location 2 . The study also demonstrated that alkalinity as well as 
acidity of the soil influence the uptake of heavy metals into tomato cells. Farmers will thus be alerted on the possible implications of using tannery sludge for plant growth boosting strategy, and further research is needed on the likely health implications attendant to consuming tannery sludge-grown vegetables on a long term basis following the biomagnification of the heavy metals in the human body.

\section{ACKNOWLEDGEMENT}

We express our sincere gratitude to Directorate of Research and Development, Nigerian Institute of Leather and Science Technology (NILEST) Zaria, Kaduna State, Nigeria. The senior technologists, at both Chemistry Laboratory, Federal University Dutse, Nigeria, and Soil and Water Laboratory, Bayero University Kano, Nigeria, we are grateful. Our huge thanks also go to the entire staff and the famous pioneering students, Department of Environmental Management and Toxicology, Federal University Duste, Nigeria for their priceless support.

\section{REFERENCES}

[1]. Abdallah, M. S., Ibrahim, M., \& Warodi, F. A. (2017). REVIEW ON SOME PLANTS AS BIO PESTICIDES. International Journal of Contemporary Research and Review. https://doi.org/10.15520/ijcrr/2017/8/07/203

[2]. Angela, A. D., Jennifer, M., \& Ibrahim, M. (2019). Assessment of the Quality of Water from Rooftops (A Case Study of "Nkamponasi" in Tarkwa, Ghana). International Journal of Scientific and Research Publications (IJSRP), 9(5), p8941. https://doi.org/10.29322/ijsrp.9.05.2019.p8941

[3]. Arora, M., Kiran, B., Rani, S., Rani, A., Kaur, B., \& Mittal, N. (2008). Heavy Metal Accumulation in Vegetables Irrigated With Water from
Different Sources. Food Chemistry, 111, 811815.

[4]. Astawan, M. (2008). Bahaya Logam Berat Dalam Makanan (Risk of Heavy Metals in Foods). Kompas. Com. [online] Available:http://kesehatan.kompas.com/read/20 08/09/21/11254074/ (September 21, 2008).

[5]. Behbahaninia, A. \& Mirbagheri, S. A. (2008). Investigation of Heavy Metals Uptake by Vegetable Crops from Metal-Contaminated Soil. World Academy of Science, Engineering and Tehnology, 43, 56-58.

[6]. Brempong, L. N., Dawoe, E., \& Ibrahim, M. (2019). Assessment of the Effect of Biochar and Leucaena Leucocephala on the Growth and Yield of Maize (Zea mays). International Journal of Scientific Research in Science and Technology, 34-45. https://doi.org/10.32628/ijsrst19641

[7]. Cobb, G. P., Sands, K., Waters, M., Wixson, B. G., \& Dorward-King, E. (2000). Accumulation of Heavy Metals by Vegetables Grown in Mine Wastes. Environ. Toxicol. Chem., 19(3), 600607.

[8]. Cui, Y-J., Zhu, Y-G., Zhai, R-H., Chen, D-Y., Huang, Y-Z., Qiu, Y., \& Liang, J-Z. (2004). Transfer of Metals from Soil to Vegetables in an Area Near a Smelter in Nanning, China. Environment International, 30, 785-791.

[9]. Gupta, D.K. and Sandalion, L.M. (2012). Metal Toxicity in Plants: Perception, Signalling and Remediation. Springer-Verlag Berlin Heidelberg, London.

[10]. Gupta, A. K and Sinha, S. (2007). Phytoextraction Capacity of the Plants Growing on Tannery Sludge Dumping Sites. Journal of Bioresource Technology. Vol 98(9)178894.available At https://www.researchgate.net/.../6818416...

[11]. Ibrahim, M, Daniel, A. K., Kiyawa, S. A., \& Kutama, A. S. (2017). Phyto-Accumulation of Lead and Chromium in Common Edible Green- 
Leafy Vegetables Consumed in Dutse Metropolis, Jigawa State, Nigeria. In International Jour. In International Journal of Chemical, Material and Environmental Research (Vol. 2017, Issue 3). www.ijcmer.org

[12]. Ibrahim, Muhammad. (2019). Air Quality Analyses for Photochemical Smog Associated with Atmospheric Aerosol Particles and Ozone Precursors Using CMAQ and CAMx Modeling Systems. International Journal of Scientific Research in Science and Technology, 224-235. https://doi.org/10.32628/ijsrst196530

[13]. Kachenko, A. \& Singh, B. (2004). HeavyMetals Contamination of Home Grown Vegetables Near Metal Smelter in NSW. 3th Australian New Zealand Soils Conference, 5-9 December 2004. University of Sydney, Australia

[14]. Khadija, B. U., \& Ibrahim, M. (2019). Assessment of the Pollution extent of Sulphur Dioxide (SO2) and Nitrogen Dioxide (NO2) in Ambient air within Kano Metropolis, Kano State, Nigeria. Journal of Environmental Science, Computer Science And Engineering \& Technology, 8(8), 396-404. https://doi.org/10.24214/jecet.A.8.4.39604.

[15]. Nanven Nimyel, D., Egila, J.N and Lohdip, Y.N. (2015). Heavy Metal Concentrations in some Vegetables Grown in a Farm Teated with Urban Solid Waste in Kuru Jantar, Nigeria. British Journal of Applied Science and Technology. Vol 8, No.2,pp139-147.

[16]. Ogunyemi, S., Awodoyin, R.O., and Opadeji, T.(2003).Urban Agricultural Production: Heavy Metal Contamination of Amaranthus cruenties L. Grown on Domestic Refuse landfill Soil in Ibadan, Nigeria. Emirate Journal of Agricultural Science.Vol 15(2): 87-94.

[17]. Okoronkwo, NE., Igwe, JC., \& Onwuchekwa, EC. (2005). Risk and Health Implications of Polluted Soils for Crop Production. African Journal of Biothecnology, 4(1), 1521-1524
[18]. Oluyemi, E.A., Feuyit, G., Oyekunle, J.A.O., and Ogunfowokan, A.O. (2008). Seasonal Variations in Heavy Metal Concentrations in Soil and Some Selected Crops at a Landfill in Nigeria. African Journal of Environmental Science and Technology.Vol 2(5): 089-096.

[19]. Oyeleke, P.O., Abiodun, O.A., Salako, R.A., Odeyemi, O.E. and Abejide, T.B (2015). Assessment of Some Heavy Metals in the Surrounding Soils of Automobile Battery Factory in Ibadan, Nigeria. African Journal of Environmental Science and Technology. Vol 10(1) pp 1-8.

[20]. Voutsa, D., Grimanis, A., \& Samara, C. (1996). Trace Elements in Vegetables grown in an industrial Area in Relation to Soil and Air Particulate Matter. Environmental Pollution, 94(3), 325-335.

\section{Cite this article as :}

Abigail Clement Young, Muhammad Ibrahim, "Bioaccumulation of Heavy Metals in Lycopersicon Esculentum Grown with Tannery Sludge across Some Selected Farmlands in Dawakin Kudu LGA of Kano State, Nigeria", International Journal of Scientific Research in Science and Technology (IJSRST), Online ISSN: 2395-602X, Print ISSN: 2395-6011, Volume 8 Issue 2, pp. 251-257, March-April 2021. Available at doi: https://doi.org/10.32628/IJSRST218238 Journal URL: https://ijsrst.com/IJSRST218238 